Available online at: http://journal.unj.ac.id

Jurnal

Pensil

Pendidikan Teknik Sipil

Journal homepage: http://journal.unj.ac.id/unj/index.php/ipensil/index

\title{
HUBUNGAN BERPIKIR KRITIS DAN MOTIVASI BELAJAR TERHADAP HASIL BELAJAR DI MASA PANDEMI COVID 19
}

\section{THE CORRELATION OF CRITICAL THINKING AND LEARNING MOTIVATION TO LEARNING OUTCOMES IN COVID 19 PANDEMIC ERA}

\author{
Endah Sri Wabyuni', Henita Rabmayanti², Ilmi Zajuli Ichsan ${ }^{3}$ \\ ${ }^{1}$ SMK Negeri 1 Jakarta, Jl. Budi Utomo No. 7, DKI Jakarta, 10710, Indonesia \\ ${ }^{2,3}$ Universitas Negeri Jakarta, Jl. Rawamangun Muka Raya No. 11, DKI Jakarta, 13220 \\ 1endahdara630@gmail.com,, henita.rahmavanti@unj.ac.id, 3 ilmizajuli95@gmail.com
}

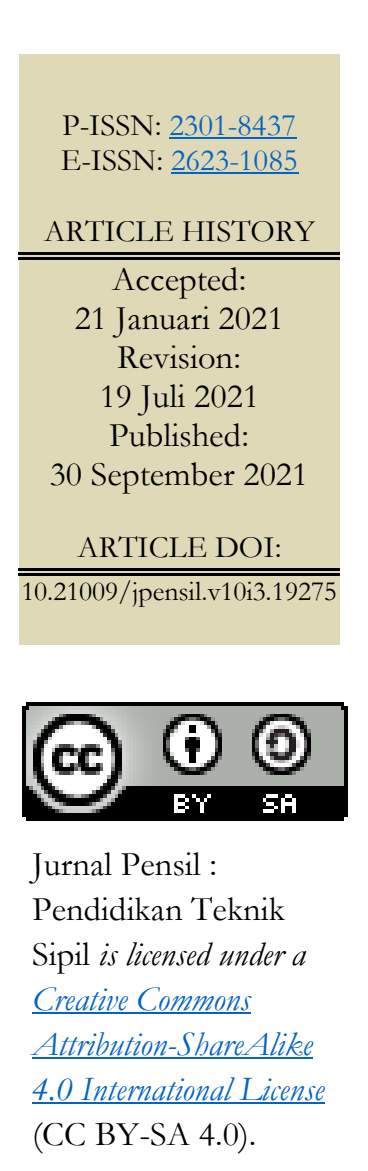

Abstrak
Dalam pembelajaran daring, banyak kendala yang dihadapi baik siswa maupun guru, hal ini dikarenakan siswa dan guru tidak dapat berinteraksi seperti pada pembelajaran tatap muka sehingga siswa mengalami kesulitan dalam menangkap materi yang disampaikan oleh guru. Untuk mendapatkan hasil belajar yang sesuai dengan kriteria ketuntasan minimal, maka siswa dituntut untuk mandiri, mempunyai daya berpikir kritis dan motivasi belajar yang tinggi. Penelitian ini bertujuan untuk mengetahui seberapa besar korelasi/pengaruh antara berpikir kritis, motivasi belajar, dan hasil belajar siswa. Metode yang digunakan adalah kuantitatif korelatif, dengan analisis data menggunakan SPSS. Pengambilan data dilakukan dengan sebaran angket melalui Google Form. Penelitian dilaksanakan di salah satu SMK Negeri di Jakarta dengan populasi siswa kelas X DPIB sebanyak 70 siswa dan sampel diambil 40 siswa. Hasil belajar yang di gunakan adalah hasil belajar nilai ketrampilan mata pelajaran Gambar Teknik yang diambil dari hasil nilai tugas selama satu semester. Hasil penelitian yang didapat ternyata kemampuan berpikir kritis siswa mempunyai korelasi dengan hasil belajar jika siswa memahami materi yang disampaikan oleh guru dan mempunyai media pembelajaran yang memadai, sedangkan semangat belajar mempunyai korelasi positif dengan derajat sedang dan signifikan terhadap hasil belajar. Jika semangat belajar tinggi, maka akan mendapatkan hasil belajar yang baik.

Kata kunci: Pembelajaran Daring, Berpikir Kritis, Motivasi Belajar, Hasil Belajar

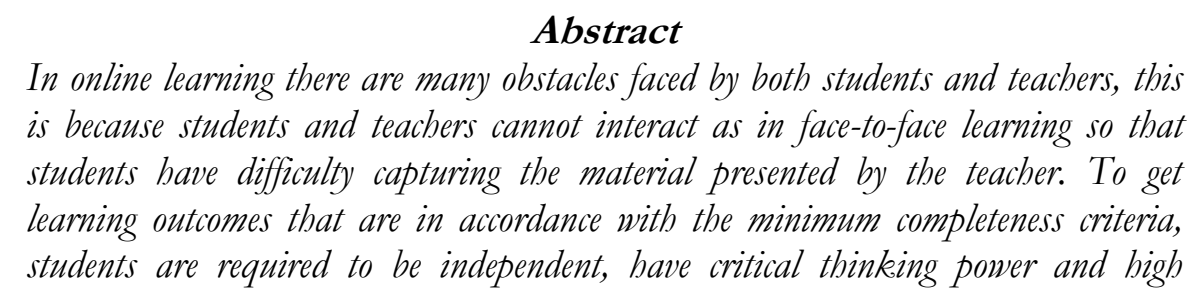


learning motivation. This study aims to determine how big the correlation/influence between critical thinking, learning motivation and student learning outcomes. The method used is quantitative correlation, with data analysis using SPSS. The research was conducted in one of the State Vocational High Schools in Jakarta with a population of students of class X DPIB and 40 students were taken as samples. The learning outcomes used are the results of learning the value of the Engineering Drawing subject skills taken from the results of the value of the assignment for one semester. The results of the study showed that students' critical thinking skills had a correlation with learning outcomes if students understood the material presented by the teacher and had adequate learning media. Meanwhile, the spirit of learning has a positive correlation with moderate and significant degrees of learning outcomes. If the enthusiasm for learning is high, it will get good learning outcomes.

Keywords: Online Learning, Critical Thinking, Learning Motivation, Learning Outcomes

\section{Pendahuluan}

Sejak awal tahun 2020 salah satu negara yang terkena dampak Corona Virus Disease 2019 adalah negara Indonesia. Di Indonesia kasus pertama yang terdapak Covid-19 terkonfirmasi dua orang yang terkena covid-19 pada tanggal 2 Maret 2020, Susilo at al, (2020). Kasus terkonfirmasi positif Covid-19 hingga 31 Desember 2020 sebanyak 743.198 orang, terkonfirmasi sembuh 611.097 orang dan terkonfirmasi meninggal 22.138 orang. Munculnya virus ini telah mempengaruhi berbagai aspek kehidupan. Upaya pemerintah untuk mencegah penyebaran virus dilakukan dengan mengeluarkan bebagai kebijakan, salah satu kebijakan yang berkaitan dengan pendidikan adalah dengan menutup segala kegiatan yang ada di sekolah dan dengan memberlakukan sistem belajar online/daring. Kegiatan pembelajaran daring ini diberlakukan berdasarkan pada Surat Edaran Kemendikbud Nomor 40 Tahun 2020 Tentang Pelaksanaan Kebijakan Pendidikan dalam Masa Darurat Penyebaran Corona Virus Disease (COVID19), Dewi, (2020). Menurut Ramanta \&Dwi
Wijayanti, (2020) kelebihan dari pembelajaran daring adalah siswa menjasi lebih kreatif, disiplin, mandiri dan bertanggung jawab dalam melaksanakan tugas, sedangkan kelemahanya adalah pemahaman siswa tentang materi yang disampaikan guru kurang maksimal karena guru menyampaikan materi kurang lengkap dan rinci. Untuk pelaksanaan pembelajaran daring guru dan siswa menggunakan aplikasi yang tersambung dengan internet seperti whatsapp dan google classroom dengan menggunakan media pembelajaran smartphone, laptop atau komputer. Melalui penggunaan media ini, maka guru harus kreatif untuk menyampaikan materi sehingga terlihat menarik untuk siswa, Nuriansyah, (2020). Dalam pembelajaran daring, guru dan siswa tidak bertemu secara langsung, tetapi segala aktivitas yang seharusnya di kerjakan di sekolah kini kerjakan dari rumah dengan sistem online. Mulai dari memberi materi online, tugas online, tes online dan lain sebagainya. Untuk pemberian materi guru dapat melakukannya dengan cara video conference, e- learning atau distance learning,Diana Novita, (2020) 
SMK sebagai salah satu jenis pendidikan di Indonesia juga mengikuti kebijakan pemerintah yaitu melakukan proses pembelajaran secara daring. Sekolah kejuruan mempunyai tujuan menyiapkan peserta didik untuk bekerja pada bidang tertentu seperti yang tercantum dalam Undang-Undang Sistem Pendidikan Nasional Nomor 20 tahun 2003, Arfandi, (2009). Berdasarkan tujuan pendidikan kejuruan tersebut, maka pembelajaran di SMK memiliki porsi pembelajaran praktek lebih besar dibandingkan dengan pembelajaran teori. Pembelajaran daring siswa tidak dapat melakukan pembelajaran praktek di bengkel dengan melihat langsung contoh ataupun cara (langkah kerja) yang di perlihatkan oleh guru. Siswa hanya bisa melihat cara (langkah kerja) melalui media pembelajaran online seperti video yang ada di youtube dan media sosial yang lain. Selain itu, banyak siswa ataupun guru yang mempunyai keterbatasan media pembelajaran seperti smartphone, laptop atau komputer, dan kuota internet dan juga banyak yang terkendala dengan bagaimana cara menggunakan fitur aplikasi yang digunakan untuk pembelajaran. Wahyono et al, (2020) menyebutkan bahwa pembelajaran daring memiliki banyak hambatan atau kendala, contohnya adalah hambatan dari sarana dan prasarana serta sumber daya manusia.

Perbedaan metode pembelajaran dari tatap muka menjadi daring (dalam jaringan) menuntut daya berpikir kritis siswa yang tinggi. Bunt \& Gouws, (2020); Davut Gul \& Akcay, (2020), menyebutkan dengan berpikir kritis siswa akan mampu memanfaatkan media sosial untuk mendapatkan segala informasi. Seseorang dapat mengevaluasi dan menganalisis segala sesuatu menggunakan berbagai proses mental seperti memusatkan perhatian, mengkategorisasi, pemilihan, dan penilaian dengan kemampuanya dalam berpikir kritis, Cottrell dalam Nadeak et al, (2020). Untuk dapat memahami dunia dan lingkungannya seorang siswa harus mempunyai kemampuan berpikir kritis, Sheffield Jr dalam Nadeak\&Naibaho, (2020). Glaser dalam Fisher, (2009, p.3) mendefinisikan berpikir kritis sebagai sebuah metode pemeriksaan dan penalaran yang logis dan ketrampilan untuk menerapkan metode tersebut dalam bersikap berpikir secara mendalam tentang masalah dan segala hal yang berada dalam jangkauan pengalamannya. Upaya keras untuk memeriksa setiap keyakinan atau pengetahuan asumtif berdasarkan bukti pendukungnya dan kesimpulan yang diakibatkannya adalah bentuk dari upaya berpikir kritis, Rachmantika \& Wardono, (2019). Pendapat Halpern \& Larson dalam Sulaiman \& Syakarofath, (2018, p.86) menyampaikan bahwa seseorang yang memeriksa kebenaran informasi dengan menggunakan keterangan bukti, logika dan kesadaran akan bias disebut berpikir kritis.

Selain berpikir kritis saat pembelajaran daring, siswa harus mempunyai motivasi belajar yang tinggi untuk mengikuti pembelajaran, karena dalam pembelajaran daring siswa melakukan segala kegiatan pembelajaran dirumah dengan keterbatasan sarana dan prasarana dan melakukan aktivitas pembelajaran sendiri. Dalam kondisi seperti ini siswa akan lebih mudah merasa jenuh dan mengalami kebosanan seperti yang di ungkapkan Muhibbin Syah dalam Rimbarizki, (2017) bahwa pengetahuan dan kecakapan yang diperoleh dari belajar tidak akan mengalami kemajuan jika siswa mengalami kejenuhan. Untuk itu siswa membutuhkan semangat untuk menggerakan dirinya agar tercapai hasil belajar yang baik. Seorang siswa dapat 
melakukan kegiatan belajar secara terus menerus dengan dorongan dari motivasi yang kuat, karena motivasi belajar timbul dari perasaan seseorang berupa perkembangan energi untuk mencapai tujuan, Djamarah dalam Hidayah \& Anisa, (2019). Motivasi ini sangat penting untuk keberhasilan belajar siswa dalam hal ini peran seorang guru dibutuhkan sebagai motivator, Emda, (2017). Selain guru, peran orang tua dalam pembelajaran daring ini sangatlah di butuhkan, orang tua mempunyai peran peting karena saat ini siswa melakukan segala aktivitas pembelajaran dari rumah, Cahyati \& Kusumah, (2020). Selama proses pembelajaran daring orang tua mempunyai peran sebagai guru, sebagai fasilitator sebagai director dan motivator.

Dari beberapa hasil penelitian terdahulu sudah didapatkan hubungan antara berfikir kritis dengan hasil belajar dan motivasi belajar terhadap hasil belajar. Dalam penelitian Husnah, (2017) menyebutkan bahwa terdapat hubungan yang signifikan antara berfikir kritis dan hasil belajar. Untuk menghadapi perkembangan peradaban di masa depan siswa perlu meningkatkan kemampuan berfikir kritisnya supaya dapat tergali potensi yang ada pada dirinya, Saputra at al, (2020). Menurut Cahyani at al, (2020), bahwa motivasi belajar siswa menurun selama masa pandemi. Pembelajaran daring mempunyai iklim yang berbeda dengan pembelajaran luring sehingga mempengaruhi motivasi belajar siswa. Dalam pembelajaran daring guru mengalami kesulitan utuk mengontrol dan menjaga iklim belajar sedangkan pembelajaran luring guru mampu mengkondisikan iklim atau suasana belajar di kelas yang kondusif. Hal inilah yang mempengaruhi motivasi belajar siswa karena suasana/iklim kelas mempengaruhi motivasi belajar, Sari at al, (2018). Berdasarkan hasil wawancara dengan guru pada masa pembelajaran daring ini kemampuan berpikir kritis dan motivasi belajar anak menurun, sehingga dalam penelitian ini peneliti ingin mengetahui berapa besar daya berpikir kritis siswa dan motivasi belajarnya di masa pandemi serta apakah ada hubunganya dengan ketercapaian hasil belajar siswa.

\section{Metode Penelitian}

Dalam penelitian ini metode yang digunakan adalah kuantitatif korelatif, Sugiono, (2016); Wiyono, (2007), yaitu untuk mengetahui seberapa besar hubungan berpikir kritis dan motivasi belajar sebagai variable bebas terhadap hasil belajar sebagai variable terikat pada mata pelajaran gambar teknik untuk nilai ketrampilan. Peneliti melakukan penelitian disalah satu SMKN di Jakarta, untuk kompetensi keahlian DPIB dengan populasi seluruh siswa kelas $\mathrm{X}$ berjumlah 70 siswa dan sampel 40 siswa. Metode yang digunakan untuk mengumpulkan data berpikir kritis dan motivasi belajar dengan cara angket yang diisi oleh siswa melalui google form dengan teknik analisis data menggunakan analisis deskriptif. Analisis product momen digunakan untuk menguji hipotesis variabel bebas (berpikir kritis dan motivasi belajar) dan variable terikat (hasil belajar, untuk menguji ketiga variable tersebut secara bersama-sama menggunakan uji korelasi ganda. Untuk menghitung data yang didapat (menganalisis) menggunakan software SPSS (Statistical Product and Service Solutions).

\section{Hasil Penelitian dan Pembahasan}

Setelah dilakukan pengambilan data dengan angket secara online, didapatkan data 
berpikir kritis, motivasi belajar dan hasil belajar siswa pada mata pelajaran gambar teknik, seperti yang terlihat pada tabel berikut :

Tabel 1. Data Berpikir Kritis

\begin{tabular}{lllll}
\hline No. & $\begin{array}{l}\text { Kategor } \\
\mathbf{i}\end{array}$ & $\begin{array}{l}\text { Interva } \\
\mathbf{1}\end{array}$ & $\begin{array}{l}\text { Frekuens } \\
\mathbf{i}\end{array}$ & $\mathbf{\%}$ \\
\hline 1. & $\begin{array}{l}\text { Sangat } \\
\text { Tinggi }\end{array}$ & $136-160$ & 0 & 0 \\
\hline 2. & Tinggi & $110-135$ & 12 & 30 \\
\hline 3. & Sedang & $84-109$ & 28 & 70 \\
\hline 4. & Rendah & $59-84$ & 0 & 0 \\
\hline 5. & $\begin{array}{l}\text { Sangat } \\
\text { Rendah }\end{array}$ & $32-58$ & 0 & 0 \\
& & &
\end{tabular}

\begin{tabular}{lll}
\hline Jumla & 40 & 10 \\
$\mathrm{~h}$ & & 0
\end{tabular}

Dari tabel diatas terlihat bahwa siswa yang memiliki daya berpikir kritis paling banyak terdapat dalam kategori sedang dengan prosentase 66,7 persen, sedangkan berpikir kritis dengan katogori tinggi 31,1 persen dan berpikir kritis kategori rendah 2,2 persen.

Tabel 2. Data Motivasi Belajar

\begin{tabular}{lllll}
\hline No. & $\begin{array}{l}\text { Kategor } \\
\mathbf{i}\end{array}$ & $\begin{array}{l}\text { Interva } \\
\mathbf{1}\end{array}$ & $\begin{array}{l}\text { Frekuens } \\
\mathbf{i}\end{array}$ & $\mathbf{\%}$ \\
\hline 1. & $\begin{array}{l}\text { Sangat } \\
\text { Tinggi }\end{array}$ & $\begin{array}{l}120- \\
140\end{array}$ & 2 & 5 \\
& & & & \\
\hline 2. & Tinggi & $99-199$ & 31 & $\begin{array}{l}77, \\
\end{array}$ \\
& & & & 5 \\
\hline 3. & Sedang & $78-98$ & 7 & 17, \\
& & & & 5 \\
\hline 4. & Rendah & $57-77$ & 0 & 0 \\
\hline 5. & Sangat & $35-56$ & 0 & 0 \\
\hline
\end{tabular}

\begin{tabular}{lcc}
\hline \multicolumn{2}{c}{ Rendah } & \\
\\
\hline Jumla & 40 & 100 \\
$\mathrm{~h}$ & & \\
\hline
\end{tabular}

Berdasarkan data di atas dapat dilihat bahwa siswa yang memiliki motivasi belajar paling banyak terdapat dalam kategori tinggi yaitu 77,8 persen, sedangkan yang memiliki motivasi belajar sangat tinggi hanya 4,4 persen, dan yang memiliki motivasi belajar dengan kategori sedang sebanyak 17,8.

Tabel 3. Hasil Belajar

\begin{tabular}{lllll}
\hline No. & $\begin{array}{l}\text { Kategor } \\
\mathbf{i}\end{array}$ & $\begin{array}{l}\text { Interva } \\
\mathbf{1}\end{array}$ & $\begin{array}{l}\text { Frekuens } \\
\mathbf{i}\end{array}$ & $\mathbf{\%}$ \\
\hline 1. & $\begin{array}{l}\text { Sangat } \\
\text { Baik }\end{array}$ & $91-100$ & 0 & 0 \\
\hline 2. & Baik & $83-90$ & 18 & 45 \\
\hline 3. & Cukup & $75-82$ & 19 & 47, \\
& & & & 5 \\
\hline 4. & Rendah & $0-74$ & 3 & 7,5 \\
\hline $\begin{array}{l}\text { Jumla } \\
\text { h }\end{array}$ & & & 40 & 100 \\
\end{tabular}

Dari hasil analisis deskriptif hasil belajar didapat nilai tertinggi 88 dan nilai terendah 62 , dengan rata-rata nilai 80,63 dan median 82, dengan kategori paling tinggi dalam penlaian terdapat pada kategori cukup yaitu sebesar 47,5 persen, dan kategori baik 45 persen sedangkan kategori rendah 3 persen.

Selanjutnya untuk mengetahui seberapa besar hubungan berpikir kritis dengan hasil belajar, motivasi belajar dengan hasil belajar dan berpikir kritis bersama motivasi belajar dengan hasil belajar dilakukan uji korelasi yang hasilnya sebagai berikut : 
Tabel 4. Uji Korelasi Berpikir Kritis dengan Hasil Belajar

\begin{tabular}{|c|c|c|c|c|}
\hline \multirow[t]{2}{*}{ Variable } & \multirow[t]{2}{*}{$\mathbf{N}$} & \multirow[t]{2}{*}{ Sig. } & \multicolumn{2}{|c|}{$\begin{array}{l}\text { Pearson } \\
\text { Correlation }\end{array}$} \\
\hline & & & $\begin{array}{l}\text { Berpikir } \\
\text { Kritis }\end{array}$ & $\begin{array}{l}\text { Hasil } \\
\text { Belajar }\end{array}$ \\
\hline $\begin{array}{l}\text { Berfikir } \\
\text { Kritis }\end{array}$ & 40 & 0.052 & 1 & 0.309 \\
\hline $\begin{array}{l}\text { Hasil } \\
\text { Belajar }\end{array}$ & 40 & 0.052 & 0.309 & 1 \\
\hline
\end{tabular}

Dari hasil uji korelasi variable X1 (berfikir kritis) dan variable $\mathrm{Y}$ (hasil belajar) didapat nilai signifikansi $0.052>0.05$ yang artinya adanya korelasi lemah antara berpikir kritis dengan hasil belajar. Hal ini berbeda dengan hasil penelitian Mudita at al, (2019) bahwa semakin tinggi kemampuan berpikir kritis siswa maka semakin tinggi kompetensi yang dimiliki siswa. Dalam penelitian ini banyak factor yang mempengaruhi hasil penelitian diantaranya, data diambil secara online sehingga peneliti tidak bisa mengamati keseriusan siswa dalam mengisi angket, pembelajaran dilaksanakan secara daring sehingga guru harus lebih kreatif dalam menentukan model pembelajaran.

Tabel 5. Besarnya Korelasi Berpikir Kritis dengan Hasil Belajar

\begin{tabular}{|c|c|c|c|c|}
\hline Model & $\mathbf{R}$ & $\begin{array}{l}\mathbf{R} \\
\text { Square }\end{array}$ & $\mathbf{F}$ & Sig. \\
\hline 1 & 0.309 & 0.096 & 4.013 & 0.052 \\
\hline
\end{tabular}

korelasi/hubungan (R) /Nilai R $=0.309$. Dari output tersebut diperoleh koefisien determinasi ( $\mathrm{R}$ square ) sebesar 0.096, ini berarti bahwa pegaruh variable bebas X1 ( Berpikir Kritis ) terhadap variable terikat $\mathrm{Y}$ ( hasil belajar gambar tenik) adalah sebesar $9,6 \%$ dan $90,4 \%$ nya adalah factor lain, hal ini juga berarti bahwa derajat hubungan antaran berpikir kritis dan hasil belajar lemah.

Tabel 6. Uji Korelasi Motivasi Belajar dengan Hasil Belajar

\begin{tabular}{|c|c|c|c|c|}
\hline \multirow[t]{2}{*}{ Variable } & \multirow[t]{2}{*}{$\mathbf{N}$} & \multirow[t]{2}{*}{ Sig. } & \multicolumn{2}{|c|}{$\begin{array}{l}\text { Pearson } \\
\text { Correlation }\end{array}$} \\
\hline & & & $\begin{array}{l}\text { Berpikir } \\
\text { Kritis }\end{array}$ & $\begin{array}{l}\text { Hasil } \\
\text { Belajar }\end{array}$ \\
\hline $\begin{array}{l}\text { Berfikir } \\
\text { Kritis }\end{array}$ & 40 & 0.003 & 1 & 0.459 \\
\hline $\begin{array}{l}\text { Hasil } \\
\text { Belajar }\end{array}$ & 40 & 0.003 & 0.459 & 1 \\
\hline
\end{tabular}

Dari hasil uji korelasi variabel $\mathrm{X} 2$ (semangat belajar) dengan variabel Y (hasil belajar) didapatkan nilai signifikansi $0.003<0.005$. Hal ini menunjukkan bahwa terdapat korelasi antara motivasi belajar dengan hasil belajar dengan korelasi sedang dan bentuk hubungan positif.

Tabel 7. Besarnya Korelasi Semangat Belajar dengan Hasil Belajar

\section{$\begin{array}{lllll}\text { Model } & \mathbf{R} & \mathbf{R} & \mathbf{F} & \text { Sig. }\end{array}$ Square}

$\begin{array}{lllll}1 & 0.459 & 0.211 & 10.132 & 0.0003\end{array}$

Dari tabel di atas besarnya nilai korelasi $(\mathrm{R})=0.459$. Dari output tersebut diperoleh koefisien determinasi ( $\mathrm{R}$ square) sebesar 0.211 yang menunjukkan bahwa pengaruh variabel bebeas X2 (motivasi belajar) terhadap variabel terikat $\mathrm{Y}$ (hasil belajar) adalah sebesar 21,1\%, sedangkan $78,9 \%$ dari faktor lain.

Tabel 8. Uji Korelasi Berpikir Kritis dan Motivasi dengan Hasil Belajar

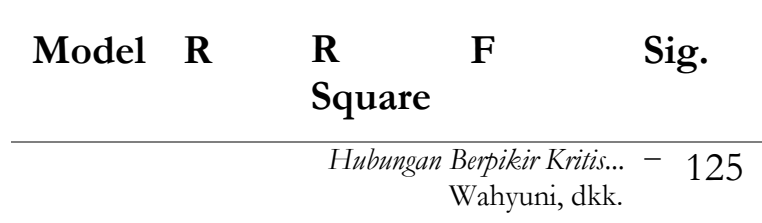




\section{$\begin{array}{lllll}1 & 0.459 & 0.211 & 4.934 & 0.013\end{array}$}

Dari tabel diatas didapat besarnya nilai signifikasnsi $0.013<0.05$, ini artinya ada korelasi antara variable X1 (berpikir kritis) dan variable X2 (motivasi belajar) dengan variable $\mathrm{Y}$ (hasil belajar), dengan nilai korelasi $(\mathrm{R})=0.459$ tingkat derajat hubungan sedang. Sedangkan kooefisien determinasi ( $\mathrm{R}$ square) sebesar 0.211 hal ini berarti pengaruh berfikir kritis bersama dengan motivasi belajar dengan hasil belajar sebesar $21,1 \%$.

Berdasarkan hasil uji korelasi variable diatas bahwa untuk variable berpikir kritis ternyata mempunyai korelasi lemah dan tidak signifikan dengan hasil belajar, dalam hal ini hasil belajarnya adalah hasil belajar ketrampilan (praktek menggambar). Adanya korelasi lemah dan tidak signifikan antara berfikir kritis dengan hasil belajar disebabkan beberapa factor antara lain siswa mempunyai keterbatasan alat untuk melaksanakan praktek gambar dan juga mengalami kesulitan saat menggunakan alat gambar, siswa sulit untuk menyerap materi teori dari gambar teknik. Dalam teori proser disebutkan bahwa pendidikan vokasi/kejuruan yang efektif hanya dapat diberikan jika tugas latihan dilakukan dengan cara, alat, dan mesin yang sama seperti yang diterapkan di tempat kerja, jika individu dilatih secara langsung dan spesifik untuk membiasakan bekerja dan berfikir secara teratur dan menumbuhkan kebiasaan kerja yang efektif kepada siswa akan terjadi hanya jika pelatihan dan pembelajaran yang diberikan berupa pekerjaan nyata dan bukan sekedar latihan. Sehingga jika melihat teori proser tersebut maka pembelajaran daring ini tidak sesuai dengan enam belas prinsip teori kejuruan dari Prosser, Proser dalam Sudira, (2013,pp.6-8) Selain itu guru harus dapat melaksanakan pembelajaran yang mecangkup aspek kognetif, afektif dan psikomotorik, Khansa, (2017).

Dari Uji korelasi motivasi belajar dengan hasil belajar didapatkan motivasi belajar mempunyai korelasi dan signifikan terhadap hasil belajar dengan derajat korelasi sedang dan bentuk hubugan positif, yang artinya jika motivasi belajar siswa tinggi maka hasil belajarnyapun akan meningkat. Saptono, (2016) menyatakan siswa yang mempunyai motivasi kuat akan memiliki semangat belajar yang tinggi untuk meraih prestasi. Salah satu penyebab rendahnya keberhasilan belajar adalah kurangnya/rendahnya motivasi belajar siswa. Hasil pengujian statistik juga menunjukan berpikir kritis dan motivasi belajar bersama-sama secara simultan memberikan kontribusi signifikan dengan derajat korelasi sedang.

\section{Simpulan}

Dari hasil analisis data yang telah dilakukan oleh peneliti didapatkan kesimpulan bahwa kemampuan berpikir kritis siswa akan berkorelasi dengan hasil belajar jika siswa didukung dengan media dan alat pembelajaran yang sesuai dan pemahaman materi. Dalam pelaksanaan pembelajaran daring siswa dan guru masih mempunyai kedala baik media dan alat belajar serta kesulitan dalam interaksi antara guru dan siswa. Untuk meningkatkan berpikir kritis siswa maka guru perlu memilih model pembejaran yang sesuai dengan materi, sehingga siswa mudah memahami konsep dasar dari materi tersebut dan dapat mengaplikasikan saat melaksanakan praktek menggambar. Motivasi belajar menjadi salah satu fator penentu dalam hasil belajar, dalam 
penelitian ini didapat adanya korelasi/hubungan antara motivasi belajar dan hasil belajar dengan derajat korelasi sedang dan hubungan positif. Dengan adanya penelitian ini diharapkan untuk peneliti berikutnya dapat mengembangkan untuk mendapatkan metode belajar yang tepat sehingga kemampuan berpikir kritis siswa dapat terasah dan motivasi belajar dapat meningkat. Hal ini sejalan dengan penelitian yang dilakukan (Husnah, 2017) yang mengatakan bahwa tingkat berpikir kritis siswa secara keseluruhan memiliki hubungan fungsional secara signifikan terhadap hasil belajar dengan nilai $\mathrm{R}$ Square 0.827 atau $82,7 \%$. Semakin tinggi tingkat berpikir kritis siswa, maka semakin besar hubungan fungsional yang signifikan terhadap hasil belajar.

\section{Daftar Pustaka}

Arfandi, A. (2009). Pelaksanaan Praktek Kerja Industri Siswa Smk Program Keahlian Teknik Bangunan Di Kota Makassar. Jurnal Cakrawala Pendidikan, 2(2), 119-131. https://doi.org/10.21831/cp.v2i2.31 2

Bunt, B., \& Gouws, G. (2020). Using an artificial life simulation to enhance reflective critical thinking among student teachers. Smart Learning Environments, $\quad 7(1), \quad 12$. https://doi.org/10.1186/s40561-020$\underline{00119-6}$

Cahyani, A., Listiana, I. D., \& Larasati, S. P. D. (2020). Motivasi Belajar Siswa SMA pada Pembelajaran Daring di Masa Pandemi Covid-19. IQ (Ilmu AlQur'an): Jurnal Pendidikan Islam, 3(01), 123-140. https://doi.org/10.37542/iq.v3i01.57

Cahyati, N., \& Kusumah, R. (2020). The Role of Parents in Applying Learning at Home During the Covid Pandemic
19. Journal Golden Age, Universitas Hamranwadi, 04(1), 4-6.

Davut Gul, M., \& Akcay, H. (2020). Structuring a new socioscientific issues (SSI) based instruction model: Impacts on pre-service science teachers' (PSTs) critical thinking skills and dispositions. International Journal of Research in Education and Science, 6(1), 141-159.

https://doi.org/10.46328/ijres.v6i1.7 85

Dewi, W. A. F. (2020). Dampak COVID-19 terhadap Implementasi Pembelajaran Daring di Sekolah Dasar. Edukatif: Jurnal Ilmu Pendidikan, 2(1), 55-61. https://doi.org/10.31004/edukatif.v2 i1.89

Diana Novita, A. R. H. (2020). Plus Minus Penggunaan Aplikasi-Aplikasi Pembelajaran Daring Selama Pandemi Covid-19. Unimed Medan, June, 1-11.

Emda, A. (2017). Kedudukan Motivasi Belajar Siswa Dalam Pembelajaran. Lantanida Journal, 5(2), 1-11.

Fisher, A. (2009). Berpikir Kritis Sebuah Pengantar (alih bahasa oleh Benyamin Hadinata).

Hidayah, N., \& Anisa, W. (2019). Peningkatan Motivasi Belajar dan Kemampuan Berpikir Kritis Peserta Didik Menggunakan Model Think Pair Share Berbantuan Alat Peraga Bahan Bekas. AR-RIAYAH: Jurnal Pendidikan Dasar, 3(2), 165. https://doi.org/10.29240/jpd.v3i2.11 86

Husnah, M. (2017). Hubungan Tingkat Berpikir Kritis Terhadap Hasil Belajar Fisika Siswa Dengan Menerapkan Model Pembelajaran Problem Based Learning. Journa of Physics and Science Learning (PASCAL), 01(2), 10-17.

Kansha Isfaraini Huurun'ien, Agus Efendi, A. G. T. (2017). Jurnal Ilmiah Pendidikan Teknik Kejuruan ( JIPTEK ). Jurnal Ilmiah Pendidikan Hubungan Berpikir Kritis... - 127 Wahyuni, dkk. 
Teknik

Kejuruan,

$X(2)$,

https://jurnal.uns.ac.id/iptk.

Mudita, I. K. A., Semara Putra, D. K. N., \& Sujana, I. W. (2019). Korelasi Antara Kemampuan Berpikir Kritis Dengan Penguasaan Kompetensi Inti Pengetahuan Ips Siswa. Mimbar Ilmu, 24(1), 36. https://doi.org/10.23887/mi.v24i1.1 7408

Nadeak, B., Juwita, C. P., Sormin, E., \& Naibaho, L. (2020). Korelasi Kemampuan Berpikir Kritis Mahasiswa dan Penggunaan Media Sosial terhadap Capaian Pembelajaran pada Masa Pandemi Covid-19. Jurnal Konseling Dan Pendidikan, 8(2), 98. https://doi.org/10.29210/146600

Nadeak, B., \& Naibaho, L. (2020). the Effectiveness of Problem-Based Learning on Students' Critical Thinking. Jurnal Dinamika Pendidikan, 13(1), $1-7$. https://doi.org/10.33541/jdp.v13i1

Nuriansyah, F. (2020). Efektifitas Penggunaan Media Online Dalam Meningkatkan Hasil Belajar Pada Mahasiswa Pendidikan Ekonomi Saat Awal Pandemi Covid-19. Jurnal Pendididikan Ekonomi Indonesia, 1(2), 61-65.

https://ejournal.upi.edu/index.php/J $\mathrm{PEI} /$ article/view/28346

Rachmantika, A. R., \& Wardono. (2019). Peran Kemampuan Berpikir Kritis Siswa Pada Pembelajaran Matematika dengan Pemecahan Masalah. Prosiding Seminar Nasional Matematika, 2, 439443.

Ramanta, D., \& Dwi Widayanti, F. (2020). Pembelajaran Daring di Sekolah Menengah Kejuruan Putra Indonesia Malang pada Masa Pandemi COVID19. Prosiding Seminar Bimbingan Dan Konseling, $\quad 0(0), \quad$ 61-67. http://conference.um.ac.id/index.ph $\mathrm{p} / \mathrm{bk} 2 /$ article/view/81
Rimbarizki, R. (2017). Penerapan Pembelajaran Daring Kombinasi Dalam Meningkatkan Motivasi Belajar Peserta Didik Paket C Vokasi Di Pusat Kegiatan Belajar Masyarakat (Pkbm) Pioneer Karanganyar. J+Plus Unesa, 6(2), 1-12.

Saptono Yohanes Joko. (2016). Motivasi dan keberhasilan belajar siswa. Jurnal Pendidikan Agama Kristen, I(1), 189_ 212.

Sari, D. P., Rusmin, \& Deskoni. (2018). Pengaruh Iklim Kelas Terhadap Motivasi Belajar Peserta Didik di SMAN3 Tanjung Raja. Jurnal PROFIT Kajian Pendidikan Ekonomi Dan Ilmu Ekonomi, 5(1), 80-88.

Sudira, P. (2013). Praksis Pendidikan Kejuruan Indonesia diantara Mazab John Dewey dan Charles Prosser. Seminar Pendidikan Vokasi Sebagai Disiplin Keilmuan, 1-13. http://staff.uny.ac.id/sites/default/fil es/penelitian/dr-putu-sudira$\mathrm{mp} /$ paper-seminar-ptk-putu-s2013.pdf

Sugiono, S. (2016). Metode Penelitian Kuantitatif, Kualitatif, dan R \& D. Bandung: Alfabeta.

Sulaiman, A., \& Syakarofath, N. A. (2018). Berpikir Kritis: Mendorong Introduksi dan Reformulasi Konsep dalam Psikologi Islam. Buletin Psikologi, 26(2), 86. https://doi.org/10.22146/buletinpsik ologi.38660

Susilo, A., Rumende, C. M., Pitoyo, C. W., Santoso, W. D., Yulianti, M., Herikurniawan, H., Sinto, R., Singh, G., Nainggolan, L., Nelwan, E. J., Chen, L. K., Widhani, A., Wijaya, E., Wicaksana, B., Maksum, M., Annisa, F., Jasirwan, C. O. M., \& Yunihastuti, E. (2020). Coronavirus Disease 2019: Tinjauan Literatur Terkini. Jurnal Penyakit Dalam Indonesia, 7(1), 45. https://doi.org/10.7454/jpdi.v7i1.41 $\underline{5}$ 
implementasi, tantangan, dan solusi pembelajaran daring. Jurnal Pendidikan Profesi Guru, 1(1), 51-65. http://ejournal.umm.ac.id/index.php /jppg/article/view/12462

Wiyono, B. B. (2007). Metodologi Penelitian (Pendekatan Kuantitatif, Kualitatif, dan Action Research). Malang: Fakultas Ilmu Pendidikan Universitas Negeri Malang.

Wahyono, P., Husamah, H., \& Budi, A. S. (2020). Guru profesional di masa pandemi COVID-19: Review 